\title{
Operation mode and external carbon dose as determining factors in elemental composition and morphology of aerobic granules
}

\author{
Agnieszka Cydzik-Kwiatkowska ${ }^{1 *}$, Paulina Rusanowska1, Katarzyna Głowacka² \\ ${ }^{1}$ University of Warmia and Mazury in Olsztyn, Poland \\ Department of Environmental Biotechnology \\ ${ }^{2}$ University of Warmia and Mazury in Olsztyn, Poland \\ Department of Plant Physiology, Genetics and Biotechnology \\ *Corresponding author's e-mail: agnieszka.cydzik@uwm.edu.pl
}

\begin{abstract}
Keywords: anoxic phase, sodium acetate, granule diameter, granule morphology, calcium, phosphorus.
Abstract: The elemental composition and morphology of aerobic granules in sequencing batch reactors (GSBRs) treating high-nitrogen digester supernatant was investigated. The investigation particularly focused on the effect of the number of anoxic phases (one vs. two) in the cycle and the dose of external organics loading (450 mg $\mathrm{COD} /(\mathrm{L} \cdot \mathrm{cycle})$ vs. $540 \mathrm{mg} \mathrm{COD} /(\mathrm{L} \cdot \mathrm{cycle}))$ on granule characteristics.

Granules in all reactors were formed of many single cells of rod and spherical bacteria. Addition of the second anoxic phase in the GSBR cycle resulted in enhanced settling properties of the granules of about $10.6 \%$ and at the same time decreased granule diameter of about $19.4 \%$. The study showed that external organics loading was the deciding factor in the elemental composition of biomass. At $540 \mathrm{mg} \mathrm{COD} /(\mathrm{L} \cdot \mathrm{cycle})$ the granules contained more weight $\%$ of $\mathrm{C}, \mathrm{S}$ and $\mathrm{N}$, suggesting more volatile material in the granule structure. At lower organics loadings granules had the higher diameter of granules which limited the diffusion of oxygen and favored precipitation of mineral compounds in the granule interior. In this biomass higher content of $\mathrm{Mg}, \mathrm{P}$ and $\mathrm{Ca}$, was observed.
\end{abstract}

\section{Introduction}

Biological treatment processes use microorganisms that are immobilized on fixed or mobile carriers, or suspended in wastewater, such as activated or granular sludge. The technology of aerobic granular sludge has been dynamically developed in recent years and successfully used at a laboratory scale, in pilot plants and at a technical scale (Ni et al. 2009, Liu et al. 2011, van der Roest et al. 2011).

Aerobic granules are compact spherical clusters of microorganisms. Their surface is smooth or fluffy, depending on whether the biomass is dominated by bacteria or fungi. A characteristic feature of the granules is their layered structure. In the outer layer there are clusters of aerobic bacteria, such as autotrophic ammonium-oxidizers. In the next layers there are facultative anaerobes and then obligatory anaerobes. The deepest layer is composed of degenerated organic matter and mineral precipitates, of which considerable amounts are in the form of hydroxyapatite (Mañas et al. 2011). Accumulation of mineral compounds in the core of microbial granules can be encouraged by metabolic processes that produce alkalinity e.g. denitrification (Mañas et al. 2012). Due to the presence of many channels and pores in the granule structure it is possible to transport nutrients and oxygen to the deeper layers of the granules (Zheng and Yu 2007).
The layering of granules creates favorable conditions for the development of phosphate-accumulating and denitrifying microorganisms and makes it possible to remove $\mathrm{P}$ and $\mathrm{N}$ despite the aeration of the reactor. The removal of these biogens can be additionally improved by modifications of the GSBR cycle, such as incorporation of anaerobic and anoxic phases or addition of an external carbon source in the reactor cycle. The addition of external organics supports both denitrification and enhanced phosphorus removal. The use of acetic acid for this purpose ensures high phosphate release and binding rates. The researchers in a study in which an anaerobic phase was incorporated in the operational cycle, during which external carbon, in the form of acetate, was added, reported that COD and phosphorus were removed from slaughterhouse wastewater with a $98 \%$ efficiency (Cassidy and Belia 2005). Acetate is also a very good source of carbon for microorganisms conducting heterotrophic denitrification in aerobic granular sludge (Cydzik-Kwiatkowska et al. 2013).

Granular sludge formation is supported by the presence of divalent ions such as $\mathrm{Ca}^{2+}$ or $\mathrm{Mg}^{2+}$. A positive effect of $\mathrm{Ca}^{2+}$ on granulation can be due to calcium-induced dehydration of bacterial cell surfaces, which stimulates cell to cell aggregation and reduces the time of granulation (Jiang et al. 2003). The calcium ions are mainly accumulated in the core of the granules as $\mathrm{CaCO}_{3}$. These Ca-rich granules 
are characterized by higher mechanical strength but lower bioactivity (Ren et al. 2008). Another factor that determines the mechanical properties of granules is the presence of extracellular polymers (EPS) in their structure. EPS serve as an internal framework and a source of reserve substances for microorganisms that inhabit the granules (Sheng et al. 2010, Tu et al. 2012).

Knowledge of the elemental composition of biomass and its morphology is needed to balance transformations of nitrogen, carbon and phosphorus in GSBRs, to determine the quantity of pollutants that are incorporated into biomass, and to predict the settling properties of biomass. It has been shown that the selection of operational parameters such as hydraulic retention time (HRT), temperature, a $\mathrm{COD} / \mathrm{N}$ ratio of the influent and organics loading (Cydzik-Kwiatkowska and Wojnowska-Baryła 2011, Ebrahimi et al. 2010, Muda et al. 2011) affects the morphology of granules and their species composition. The variations of $\mathrm{Ca}, \mathrm{Mg}$ and $\mathrm{K}$ concentrations in the influent dictate the amounts of these ions in granules (Schönborn et al. 2001). The study (Takiguchi et al. 2007) showed that in activated sludge, $\mathrm{P}$ was co-localized with $\mathrm{Al}, \mathrm{Ca}$ and $\mathrm{Mg}$ on the surface of flocs, and that addition of these metals to wastewater can significantly reduce the $\mathrm{P}$ release from the biomass. It has also been demonstrated that in P-accumulating granules less than $10 \%$ of the total $\mathrm{P}$ content was in the form of phosphate-related precipitates, implying that biological phosphorus removal was mainly responsible for the $\mathrm{P}$ accumulation in the granules (Liu et al. 2005).

Less information is available on the effects of the GSBR cycle modifications on the granule properties. The aim of this study was to determine how the dose of external carbon source and the presence of an additional anoxic phase in the GSBR cycle affect the morphology and elemental composition of aerobic granules. The GSBRs were fed with anaerobic digester supernatant that was rich in inorganic forms of nitrogen and phosphorus and characterized by a low COD/N ratio. Sodium acetate was used as an external carbon source added during the reactor cycle. Changes in the elemental composition of biomass, depending on the operational parameters, were analyzed with a scanning electron microscope (SEM) combined with an energy dispersive X-ray detector (EDX).

\section{Materials and methods}

\section{GSBR operation}

The experiment was carried out in three column GSBRs (height $100 \mathrm{~cm}$, diameter $10 \mathrm{~cm}$ ) with a working volume of $4.5 \mathrm{~L}$. The reactors were operated by programmable logic controllers at a volumetric exchange rate of $62 \%$ /cycle. The GSBRs were exploited at a temperature of $26^{\circ} \mathrm{C}$, and a ratio of 7.5-8.5 $\mathrm{pH}$. The substrate for the experiment was digester supernatant $\left(290 \pm 128 \mathrm{mg} \mathrm{COD} / \mathrm{L}, 421 \pm 21 \mathrm{mg} \mathrm{NH}_{4}^{+}-\mathrm{N} / \mathrm{L}, 496 \pm 68 \mathrm{mg}\right.$ TKN/L, 327 $112 \mathrm{mg} \mathrm{P} / \mathrm{L}, 57 \pm 12 \mathrm{mg} \mathrm{Ca}^{2+} / \mathrm{L}, 52 \pm 8 \mathrm{mg} \mathrm{Mg}^{2+} / \mathrm{L}$ ) obtained by dewatering of anaerobically stabilized sewage sludge in the 'Eyna' Municipal Wastewater Treatment Plant in Olsztyn (Poland). To maintain proper alkalinity for nitrification, theoretical amounts of carbonates and carbohydrates were added to the supernatant (Villaverde et al. 1997). GSBRs were operated at an HRT of 13 hours, corresponding to a cycle length of 8 hours, but with different modes of cycle operation (Fig. 1). Sodium acetate was added in the GSBR cycle as a source of organic carbon for biomass synthesis and denitrification. In each cycle, feeding, sedimentation and discharge of treated wastewater lasted $2 \mathrm{~min}$. In aeration phases, air was supplied with a superficial velocity of $0.8 \mathrm{~cm} / \mathrm{s}(120 \mathrm{~L} / \mathrm{h})$. The reactors were operated without intentional control of sludge retention time. As a seed sludge, granular sludge from a previous experiment was used (Cydzik-Kwiatkowska et al. 2013). The adaptation of biomass to operational conditions in the reactors lasted about 70 cycles. This adaptation lasted until the values of pollutants in the effluent did not vary more than $10 \%$ from one measurement to another. After this time, regular analyses of biomass and wastewater were carried out for over 450 cycles. Biomass was analyzed every two weeks with the use of a light microscope. Because no significant changes in bacterial morphology were noted during the whole experimental period, only about 5-10 granules from each experimental GSBR were taken to visualize bacterial morphology with a scanning electron microscope (SEM).

\section{Analytical methods}

Analysis of orthophosphates, total suspended solids (TSS), volatile suspended solids (VSS), $\mathrm{Ca}, \mathrm{Mg}$, and sludge
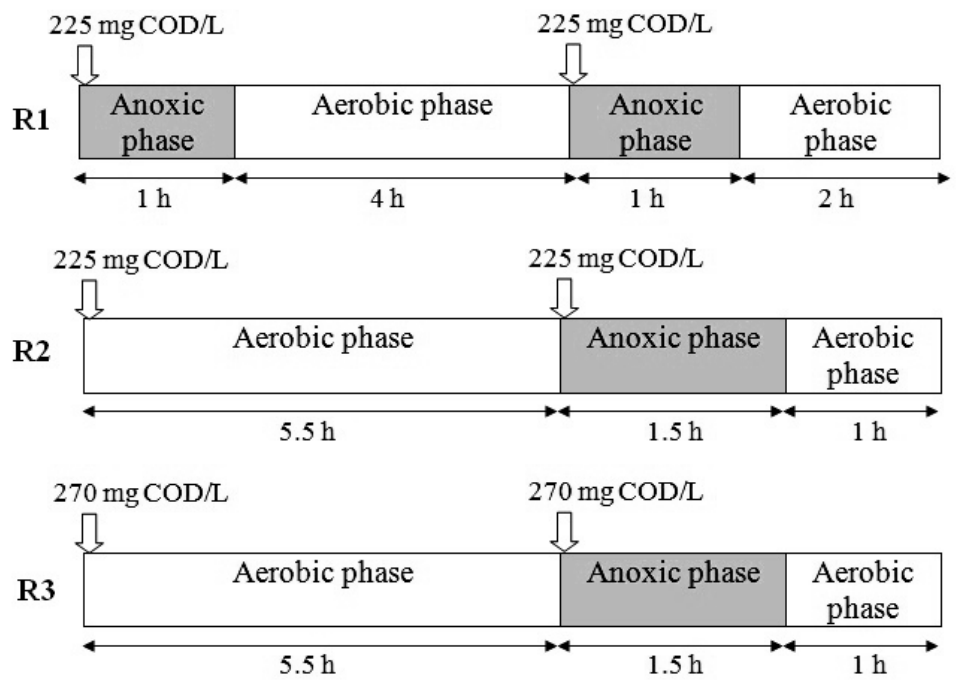

Fig. 1. Cycle configuration of the experimental reactors 
volumetric index after 5 min of sedimentation $\left(\mathrm{SVI}_{5}\right)$ were carried out (APHA 1992). Total phosphorus was analyzed with a Nanocolor kit (AQUA LAB, Poland). Granulometric composition of biomass was assessed in a Mastersizer 2000 (Malvern Instruments, United Kingdom). The aerobic granules were examined with a SEM-EDX for elemental analyses. Before measuring, the samples were fixed in a $2.5 \%$ glutaraldehyde solution (POCH, Poland). The fixed material was then rinsed two times for 20 minutes each in phosphate buffer at room temperature. The samples were dehydrated at room temperature in a graded series of ethanol concentrations of $30 \%, 50 \%, 70 \%, 80 \%$ and $96 \%$ for ten minutes in each solution and twice for 30 minutes in $99.8 \%$ ethanol $(\mathrm{POCH}$, Poland). After dehydration, the samples were dried at the critical point of $\mathrm{CO}_{2}$ (BALTEC CPD 030, Leica, Germany), placed on copper tables and sputter-coated with gold in an argon atmosphere in an ionic coater (Fine Coater, JCF-1200, JEOL, Japan). The sputter-coated material was placed in an SEM column (JSM-5310LV, JEOL, Japan with EDS Noran System 7, Thermo Scientific, USA) and analyzed at $20 \mathrm{kV}$. Collected spectra from the samples were analyzed with Point\&Select module of NSS Spectral Analysis Software, version 3.0 (Thermo Scientific, USA). The whole granule was selected as one point. In this manuscript, average results from the two independent measurements with 21 granules and 19 granules (40 analyzed granules for each reactor) are presented. The analyses were performed in the period of stable reactor performance. The SEM-EDX system was used to measure the weight $\%$ of elements in the sample. The calculated weight concentration was expressed as a percentage of element (weight $\%$ ) and showed the portion of each element in the analyzed sample. The relative intensity of an X-ray line is approximately proportional to the mass concentration of the element concerned (Castaing 1951).

\section{Statistics}

Statistical analyses were performed in STATISTICA 9.0 (StatSoft, USA). RIR Tukey or Kruskal-Wallis tests were used. A p value $\leq 0.05$ was considered significant.

\section{Results and discussion}

In the study, the elemental composition and morphology of aerobic granules in sequencing batch reactors (GSBRs) was investigated depending on the number of anoxic phases in the cycle and the dose of external organics loading. Rod (arrows) and spherical (dotted arrows) bacteria (Fig. 2) dominated on the surface and inside the granules from all reactors. Among all analyzed images, corkscrew shaped bacteria (dashed arrows) were observed only twice (Fig. 2b, 2h). Bacteria in granules formed clusters of many single cells, which built almost whole granule structure, and chains consisting of spherical shaped bacteria (Fig. 2c, 2f, 2i).
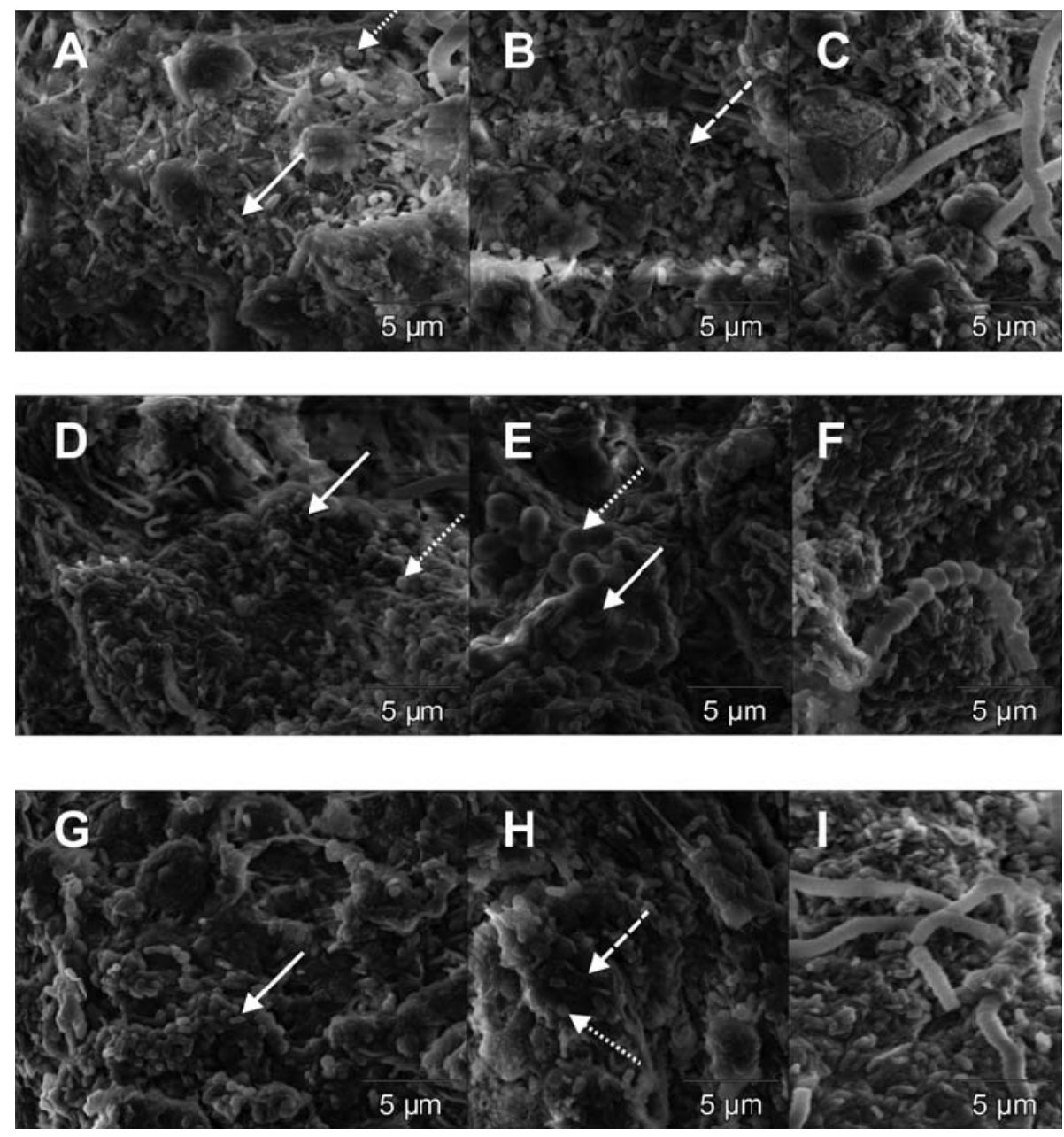

Fig. 2. SEM images of the granule surface from $a, b, c) R 1$; d, e, f) R2; and g, h, i) R3 
The concentrations of granular sludge in the experimental GSBRs did not differ significantly and remained relatively high, about $5 \mathrm{~g}$ TSS/L in R2 and R3 and $6 \mathrm{~g}$ TSS/L in R1. Granular sludge systems are recognized as having high biomass concentrations, which makes it possible to diminish the size of the reactors. However, it has been reported that TSS depends strongly on the substrate used for biomass growth. A very low biomass concentration of about $1.6 \mathrm{~g}$ TSS/L was achieved by feeding the GSBRs with waste glycerin from biodiesel production, which stimulated the growth of filamentous microorganisms (Cydzik-Kwiatkowska and Wojnowska-Baryła 2011). This growth caused fluffy granule surfaces, worsening of the settling process and resulted in biomass wash-out from the reactors, thus lowering biomass concentration. In contrast, the use of sodium acetate as a carbon source in the present study resulted in the cultivation of granules with a regular outer shape which were densely packed with microorganisms.

The granular sludge with the best settling properties described by sludge volumetric index (SVI) was found in the reactor operated with two anoxic phases in the cycle. For granular sludge, SVI values should be lower than $50 \mathrm{~mL} / \mathrm{g}$ TSS (Toh et al. 2003). The $\mathrm{SVI}_{5}$ value for the biomass from R1 was $38.4 \mathrm{~mL} / \mathrm{g}$ TSS, which was significantly lower (RIR Tukey, $\mathrm{p}<0.05)$ than in the reactors operated with shorter anoxic periods in the cycle $\left(\mathrm{SVI}_{5}\right.$ of $43-45 \mathrm{~mL} / \mathrm{g}$ TSS). A possible explanation is that the slow microbial growth that occurs in anoxic conditions (Zheng et al. 2006) favors the formation of granules with high density and mechanical strength that have better sedimentation properties.

Most of the biomass volume in the experimental reactor consisted of granules with diameters of 150-350 $\mu \mathrm{m}$ (Fig. 3). In comparison, 50-65 days after Gonzalez-Gil and Holliger (2011) began their study, most of the biomass was in the form of granules, of which $90 \%$ had a diameter larger than $500 \mu \mathrm{m}$. Although their dose of COD, in the form of acetate in the influent, was similar to the doses applied in the present study, authors had much lower nitrogen concentrations in wastewater of about $60 \mathrm{mg} \mathrm{N}-\mathrm{NH}_{4}^{+} / \mathrm{L}$. This seems to indicate that increasing $\mathrm{N}$ concentration in the influent, as in the present study, reduces the diameter of the granules.

In the two reactors that received a total dose of sodium acetate of $450 \mathrm{mg} \mathrm{COD} /(\mathrm{L} \cdot$ cycle $)$, the average granule diameter decreased about $100 \mu \mathrm{m}$ when a second anoxic phase was added to the cycle (Fig. 3). In the GSBR operated with one anoxic phase, the highest volume of biomass consisted of granules with the diameter of about $310 \mu \mathrm{m}$. Following the addition of the second anoxic phase, granules with a diameter of $250 \mu \mathrm{m}$ predominated volumetrically in the reactor. The comparison of the two reactors with one anoxic phase showed that increasing the organics dose from $450 \mathrm{mg} \mathrm{COD} /(\mathrm{L} \cdot$ cycle) to $540 \mathrm{mg} /(\mathrm{L} \cdot$ cycle $)$, both decreased the diameter of the granules and produced their greater size variation. At increased organics dose, the highest volumes of granules (about 7.5\%) were those with a diameter of about $180 \mu \mathrm{m}$.

A positive effect of the presence of an anaerobic phase in the GSBR cycle on phosphorus removal has been reported (Cassidy and Belia 2005). The authors noted 98\% effectiveness of phosphorus removal in GSBR fed with slaughterhouse wastewater with COD of $7685 \mathrm{mg} / \mathrm{L}$, total Kjeldahl nitrogen of $1057 \mathrm{mg} / \mathrm{L}$, total phosphorus $217 \mathrm{mg} / \mathrm{L}$ and VSS of $1520 \mathrm{mg} / \mathrm{L}$. The concentration of orthophosphates in the real anaerobic digester supernatant used in the presented study varied from 200 to $500 \mathrm{mg} / \mathrm{L}$. In the reactors operated with only one anoxic phase the efficiency of phosphorus removal was $14.5 \% \pm 15 \%$ and $16.3 \% \pm 20 \%$ at an external organics loading of $450 \mathrm{mg}$ $\mathrm{COD} /(\mathrm{L} \cdot$ cycle $)$ and $540 \mathrm{mg} \mathrm{COD} /(\mathrm{L} \cdot$ cycle $)$, respectively. The best efficiency of orthophosphates removal (over 18\%) was reported for R1, operated with two anoxic phases in the GSBR cycle. Regardless of the modes of operation of reactors, the efficiency of carbon compounds removal, expressed as COD, remained at around $80 \%$. Ammonium was fully removed from wastewater within the first 5 hours of the reactor cycle. The average concentrations of oxidized forms of nitrogen in the effluent were $188 \pm 44,173 \pm 49$ and $159 \pm 39 \mathrm{mg} / \mathrm{L}$ in reactors R1, R2 and R3, respectively.

SEM-EDX analysis showed that the total dose of external organics was the deciding factor in the elemental composition of the granules. The granules from all reactors were similar in composition regarding silicon, aluminum, natrium and oxygen. However, in the biomass from R3, operated at a higher dosage of organics, the $\mathrm{C}$ and $\mathrm{S}$ weight $\%$ equaled $32.8 \% \pm 5.9 \%$ and $0.3 \% \pm 0.1 \%$, respectively, and were significantly higher (RIR Tukey, $\mathrm{p}<0.05)$ than in the granules from the two remaining reactors. In R1, carbon and sulfur posed $29.4 \pm 1.4$ and $0.2 \pm 0.1 \%$, respectively, while in $\mathrm{R} 2-27.3 \% \pm 2.7 \%$ and $0.1 \% \pm 0.1 \%$. In the biomass from R3, the highest share of nitrogen was observed $(13.9 \% \pm 1.9 \%)$. There were positive correlations between $\mathrm{C}$ and $\mathrm{N}(\mathrm{R}=0.47), \mathrm{Na}(\mathrm{R}=0.59), \mathrm{S}(\mathrm{R}=0.57)$ content in granular biomass while both $\mathrm{C}$ and $\mathrm{N}$ negatively correlated with the amounts of $\mathrm{Mg}, \mathrm{P}$ and $\mathrm{Ca}$ (Table 1). Since $\mathrm{C}$ and $\mathrm{N}$ in

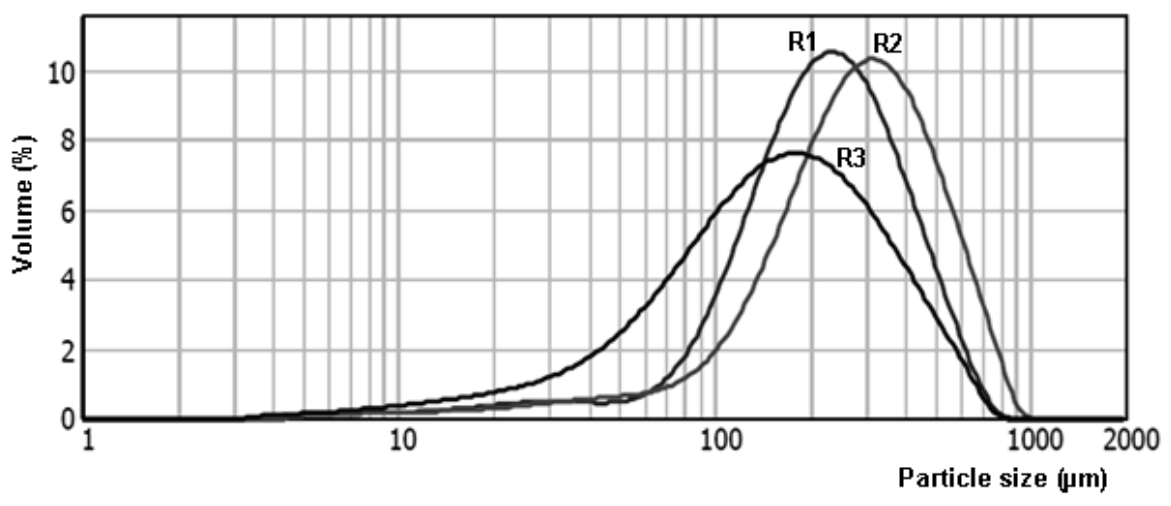

Fig. 3. The volume percentage of granules with different diameters in the GSBRs 
cells are mainly related to volatile materials (Liu et al. 2005) it can be seen that in the reactor operated at the highest organics dosage, the granules were mostly organic.

Biomass from the reactors operated at a lower external organics dose of $450 \mathrm{mg} \mathrm{COD} /(\mathrm{L} \cdot$ cycle $)$ had, on the other hand, higher content of $\mathrm{Mg}, \mathrm{P}$ and $\mathrm{Ca}$. The $\mathrm{Ca}$ and $\mathrm{Mg}$ contents in granules were correlated ( $\mathrm{R}=0.96, \mathrm{R}=0.46$, respectively) with $\mathrm{P}$ content. The abundance of $\mathrm{Mg}$, which seems to be a key element for the enhanced biological phosphorus elimination (Schönborn et al. 2001), in the granules from the reactors operated at lower dose-size of organics was 1.6- and 1.8-times higher than in the granules from R3. Comparison of the elemental composition of the biomass from the reactors operated with one anoxic phase showed that increase of the external organic dose from 450 to $540 \mathrm{mg} \mathrm{COD} /(\mathrm{L} \cdot$ cycle $)$ significantly decreased $\mathrm{P}$ and $\mathrm{Ca}$ content in the biomass from $5.2 \% \pm 1.3 \%$ and $11.4 \% \pm 3.2 \%$ in $\mathrm{R} 2$ to $3.3 \% \pm 2.0 \%$ and $7.3 \% \pm 4.9 \%$, respectively in R3. The presence of large amounts of $\mathrm{C}$, as well as $\mathrm{N}$ and $\mathrm{Mg}$ is characteristic for the peripheral organic biofilm layer of granules while $\mathrm{Ca}$ and $\mathrm{P}$ were mainly found together in the central precipitates (Juang et al. 2010, Mañas et al. 2011). P can be also found but with lower concentrations in biofilm as a result of polyphosphates in PAO clusters. It can be concluded that in R1 and R2 the higher dimensions of granules favored anaerobic conditions and precipitation of mineral compounds in the granule interior.

\section{Conclusions}

The study showed that:

- external organics loading, not the number of anoxic phases in the GSBR cycle, was the factor that decided on the elemental composition of biomass; at higher organics loading the granules contained more weight\% of $\mathrm{C}, \mathrm{S}$ and $\mathrm{N}$ and lower amounts of $\mathrm{Mg}, \mathrm{P}$ and $\mathrm{Ca}$,

- lengthening of anoxic period in the GSBR cycle by introduction of the second anoxic phase at the beginning of the cycle significantly improved sedimentation properties of aerobic granules,

- the highest efficiency of orthophosphates removal was in the reactor operated with two anoxic phases in the cycle, however there were no significant differences between the reactors,

- increase of summary external organics dose in the cycle and incorporation of the second anoxic phase in the GSBR cycle lowered granule diameters.

\section{Acknowledgements}

This work was partially supported by the Polish National Science Center project (No. 2013/09/B/NZ9/01811) and statutory project (18.610.006-300).

\section{References}

APHA. (1992). Standard Methods for the Examination of Water and Wastewater, $18^{\text {th }}$ edn. APHA, AWWA and WEF, Washington, 1992.

Cassidy, D.P. \& Belia, E. (2005). Nitrogen and phosphorus removal from an abattoir wastewater in a SBR with aerobic granular sludge, Water Research, 39(19), pp. 4817-4823.
Castaing, R. (1951). Application of electron probes to local chemical and crystallographic analysis, $\mathrm{PhD}$ Thesis, University of Paris 1951 [English translation by Duwez, P. and Wittry, D.B., California Institute of Technology, 1955].

Cydzik-Kwiatkowska, A. \& Wojnowska-Baryła, I. (2011). Nitrifying granules cultivation in a sequencing batch reactor at a low organicsto-total nitrogen ratio in wastewater, Folia Microbiologica, 56(3), pp. 201-208.

Cydzik-Kwiatkowska, A., Zielińska, M., Bernat, K., Wojnowska-Baryła, I. \& Truchan, T. (2013). Treatment of high-ammonium anaerobic digester supernatant by aerobic granular sludge and ultrafiltration processes, Chemosphere, 90(8), pp. 2208-2215.

Ebrahimi, S., Gabus, S., Rohrbach-Brandt, E., Hosseini, M., Rossi, P., Maillard, J. \& Holliger, C. (2010). Performance and microbial community composition dynamics of aerobic granular sludge from sequencing batch bubble column reactors operated at $20^{\circ} \mathrm{C}$, $30^{\circ} \mathrm{C}$, and $35^{\circ} \mathrm{C}$, Applied Microbiology and Biotechnology, 87, pp. $1555-1568$.

Gonzalez-Gil, G. \& Holliger, C. (2011). Dynamics of microbial community structure and enhanced biological phosphorus removal by aerobic granules cultivated on propionate or acetate, Applied and Environmental Microbiology, 77(22), pp. 8041-8051.

Jiang, H.L., Tay, J.H., Liu, Y. \& Tay, S.T. (2003). $\mathrm{Ca}^{2+}$ augmentation for enhancement of aerobically grown microbial granules in sludge blanket reactors, Biotechnology Letters, 25, pp. 95-99.

Juang, Y.C., Adav, S.S., Lee, D.J. \& Tay, J.H. (2010). Stable aerobic granules for continuous-flow reactors: precipitating calcium and iron salts in granular interiors, Bioresource Technology, 101, pp. 8051-8057.

Liu, Y., Lin, Y.M. \& Tay, J.H. (2005). The elemental composition of P-accumulating microbial granules developed in sequencing batch reactors, Process Biochemistry, 40, pp. 3258-3262.

Liu, Y.Q., Kong, Y., Tay, J.H. \& Zhu, J. (2011). Enhancement of start-up of pilot scale granular SBR fed with real wastewater, Separation and Purification Technology, 82, pp. 190-196.

Mañas, A., Biscans, B. \& Spérandio, M. (2011). Biologically induced phosphorus precipitation in aerobic granular sludge process, Water Research, 45, pp. 3776-3786.

Mañas, A., Pocquet, M., Biscans, B. \& Spérandio, M. (2012). Parameters influencing calcium phosphate precipitation in granular sludge sequencing batch reactor, Chemical Engineering Science, 77, pp. 165-175.

Muda, K., Aris, A., Salim, M.R., Ibrahim, Z., van Loosdrecht, M.C.M., Ahmad, A. \& Nawahwi, M.Z. (2011). The effect of hydraulic retention time on granular sludge biomass in treating textile wastewater, Water Research, 45, pp. 4711-4721.

Ni, B.J., Xie, W.M., Liu, S.G., Yu, H.Q., Wang, Y.Z., Wang, G. \& Dai, X.L. (2009). Granulation of activated sludge in a pilot-scale sequencing batch reactor for the treatment of low-strength municipal wastewater, Water Research, 43, pp. 751-761.

Ren, T.T., Liu, L., Sheng, G.P., Liu, X.W., Yu, H.Q., Zhang, M.C. \& Zhu, J.R. (2008). Calcium spatial distribution in aerobic granules and its effects on granule structure, strength and bioactivity, Water Research, 42, pp. 3343-3352.

Schönborn, C., Bauer, H.D. \& Roske, I. (2001). Stability and enhanced biological phosphorus removal and composition of polyphosphate granules, Water Research, 35, pp. 3190-3196.

Sheng, G.P., Yu, H.Q. \& Li, X.Y. (2010). Extracellular polymeric substances (EPS) of microbial aggregates in biological wastewater treatment systems: a review, Biotechnology Advances, 26, pp. 882-894.

Takiguchi, N., Kishino, M., Kuroda, A., Kato, J. \& Ohtake, H. (2007), Effect of mineral elements on phosphorus release from heated sewage sludge, Bioresource Technology, 98, pp. 2533-2537.

Toh, S.K., Tay, J.H., Moy, B.Y.P., Ivanov, V. \& Tay, S.T. (2003). Size-effect on the physical characteristics of the aerobic granule 
in a SBR, Applied Microbiology and Biotechnology, 60, pp. 687-695.

Tu, X., Song, Y., Yu, H., Zeng, P. \& Liu, R. (2012). Fractionation and characterization of dissolved extracellular and intracellular products derived from floccular sludge and aerobic granules, Bioresource Technology, 123, pp. 55-61.

van der Roest, H.F., de Bruin, L.M.M., Gademan, G. \& Coelho, F. (2011) Towards sustainable waste water treatment with Dutch Nereda ${ }^{\circledR}$ technology, Water Practice and Technology 6(3).
Villaverde, S., García-Encina, P.A. \& Fdz-Polanco, F. (1997). Influence of $\mathrm{pH}$ over nitrifying biofilm activity in submerged biofilters, Water Research, 31(5), pp. 1180-1186.

Zheng, Y.M., Yu, H.Q., Liu, S.H. \& Liu, X.Z. (2006). Formation and instability of aerobic granules under high organic loading conditions, Chemosphere, 63, pp. 1791-1800.

Zheng, Y.M. \& Yu, H.Q. (2007). Determination of the pore size distribution and porosity of aerobic granules using size-exclusion chromatography, Water Research, 41, pp. 39-46.

\section{Parametry eksploatacyjne oraz dawka zewnętrznego źródła węgla jako czynniki determinujące skład pierwiastkowy oraz morfologię granul tlenowych}

Streszczenie: W pracy określono skład pierwiastkowy oraz morfologię granul tlenowych w reaktorach porcjowych (GSBRs) oczyszczających wody nadosadowe o wysokim stężeniu azotu amonowego i niskim stosunku ChZT/N. Zbadano wpływ liczby faz anoksycznych (jedna lub dwie) w cyklu pracy GSBR i dawki zewnętrznego źródła węgla (450 mg ChZT/(1·cykl) oraz $540 \mathrm{mg} \mathrm{ChZT/(1 \cdot cykl))} \mathrm{na} \mathrm{właściwości} \mathrm{granul} \mathrm{tlenowych.}$

Granule we wszystkich reaktorach składały się z wielu pojedynczych komórek pałeczek i ziarniaków. Włączenie drugiej fazy anoksycznej w cyklu GSBR, przy danej dawce zewnętrznego źródła węgla, poprawiło właściwości sedymentacyjne osadu granulowanego o około 10,6\% przy jednoczesnym obniżeniu średnic granul o około 19,4\%. Badania wykazały, że dawka zewnętrznego źródła węgla była decydującym czynnikiem wpływającym na skład

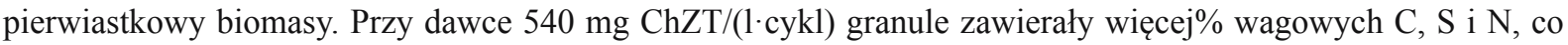
wskazywało na obecność wyższej ilości związków organicznych w strukturze osadu granulowanego. Przy niższej dawce zewnętrznego źródła węgla granule miały większe średnice, co skutkowało ograniczeniem dyfuzji tlenu i sprzyjało wytrącaniu związków mineralnych w ich wnętrzu. W tej biomasie obserwowano wyższą zawartość $\mathrm{Mg}, \mathrm{Ca}$ i P. 